\title{
Predicting Financial Distress of Manufacturing Sectors in Indonesia Using Logistic Regression
}

\author{
Ifan Wicaksana Siregar ${ }^{1}$, Eka Yulianti ${ }^{2}$ \\ \{ifan.wicaksana.s@1ecture.unjani.ac.id ${ }^{1}$, eka.yulianti@lecture.unjani.ac.id² $\}$ \\ Faculty of Economics and Business, Jenderal Achmad Yani University, Indonesia ${ }^{1}$, Faculty of Economics \\ and Business, Jenderal Achmad Yani University, Indonesia ${ }^{2}$
}

\begin{abstract}
In this era of globalization, the manufacturing sector has developed rapidly in line with the number of customers growing, but the growth has been unmatched by an increase in operating income. Therefore, it is important to analyze the financial distress of manufacturing companies to avoid bankruptcy. This study aims to determine the effect of financial ratios to predict the probability of financial distress. Financial ratio indicators use profitability ratios and leverage ratios. The population in this study are manufacturing companies listed on the Indonesia Stock Exchange 2014-2019. Based on the purposive sampling method, the financial distress criteria in this study were measured using a negative profit balance, while the statistical analysis used logistic regression with a significance level of $5 \%$. The result is the profitability ratio and the leverage ratio have a significant positive value for predicting financial difficulties.
\end{abstract}

Keywords: Profitability, Leverage, Financial Distress, Binary Logit

\section{Introduction}

The capital market as an intermediary institution today consists of various companies grouped into certain sectors. One of the sectors in the capital market is the manufacturing sector. The Central Statistics Agency noted the growth of large and medium-sized manufacturing industries was experiencing a slowdown in the second quarter of 2019 compared to the conditions in the last two years. This is because the performance of the metal goods industry, not its machines and equipment, has dropped dramatically. The growth of medium and large manufacturing industries was 3.62 percent. Meanwhile, the second quarter of 2018 was able to reach $4.36 \%$ and in 2017 it reached $3.89 \%$. However, this data shows a declining growth trend. One of the causes of the slowdown was a decline in production in a number of manufacturing industries. The metal goods industry, not machinery and equipment, was the type of industry with the most significant decline in the second quarter of July, namely up to $21.46 \%$ compared to the second quarter of the previous year.

By observing the condition of this slowdown in growth, there are even some of them that have decreased, and no growth has occurred, so companies that are members of the manufacturing industry group can make decisions and take actions to survive and not experience financial distress due to a crisis that could threaten. Companies, especially those that have encountered financial distress, should be able to conduct a predictive modeling and early treatment before going into 
bankruptcy. This analysis can also be considered for related parties, such as investors, regulators, auditors, competing companies and the wider community.

Financial distress is a stage of deteriorating financial conditions prior to bankruptcy [1]. Financial distress is a difficult condition to define. This condition can originate from the company's inability to manage the company, resulting in operating losses or net losses for the current year and/or operating cash flows that are smaller than the operating profit. If this condition cannot be recovered, it will interfere with the equity component and the company's ability to meet its longterm, even short-term obligations. Thus, financial hardship can be seen as a long-term continuum, ranging from mild to most severe [2].

Almost all studies regarding financial difficulties, measures, and financial ratios play a dominant role in almost all the variables used as predictors. This proves the fact that the ratio makes a big contribution to understanding the company's financial performance and future financial status [3]. Research related to the prediction of financial distress and bankruptcy using financial ratios as predictors has been widely conducted. Altman (1968) conducted research using the first multivariate model which produced a Z-Score to predict financial distress. This model was further refined to produce the Modified Altman Model in 1995. The Modified Altman Model involves financial liquidity ratios, financial structure, and management efficiency to predict financial distress.

Various studies on financial distress have been carried out. As stated by Iskandar [4] revealed that many studies have been carried out on the topic of financial distress both in terms of data collection techniques, analysis techniques, and so on with the objective equation that is finding optimal solutions for the estimated performance formed. Some of the models that have been made include the logit model (Rowland [5], Antikasari \& Juminah [6]; Vu [7]; Sun [8]; Hassan, Zainuddin, and Nordin [9]; Mraihi [10]; Waqas [11]; Dewi [12]; Kerroucha [13]; Jones [14]). Regarding the object of research, there are also various objects, like regional objects (country, region, etc.), industry classification, time span, economic conditions, and others. Several previous studies that conducted research on financial distress through various models showed different results including that conducted by Iskandar [15] showing the financial ratios in the company's financial statements consisted of Current Ratio (CR), Operating Profit Margin (OPM), Return On Asset (ROA), Return On Equity (ROE) and stock beta value (YLD) can be used to differentiate and classify companies into groups experiencing financial distress and non-financial distress. Based on the differences in the research results that have been started, the researcher will review and analyze financial distress using the binary logit model approach. The binary logit model approach has better prediction accuracy in the long run (over one and a half years) [16].

\section{Literature Review}

Financial problems will most likely occur if the company experiences profitability and leverage problems. If these conditions are not paid attention to and are immediately unresolved, it can result in bankruptcy. Financial distress is a condition that needs immediate attention from the company so that the company can continue surviving the company. "Financial distress is defined as a condition when a firm incurs more debt than its firm size, profitability, and asset composition can sustain. With declining ability to generate revenue coupled with inadequate cash flow from operations, a 
financially distressed firm will be trapped into severe liquidity problems, consequently affecting its solvency" [17]. This definition indicates that when financial distress occurs. It means that the company has a lot of debt compared to the value of the company, as well as a low level of profitability and even loss. This needs being a concern for the company so that the company must be able to predict the occurrence of financial distress to take preventive action.

Companies that experience financial distress can be seen or determined by various factors, namely: (1) for 2 years experiencing negative net operating income and for more than one year it has not paid dividends [18]. Employment dismissal or eliminating dividend payments [19]. (3) The company has a performance that shows negative operating profit, negative net income, negative equity book value, and the company is doing the merger. (4) Measuring financial distress by means of a smaller cash flow than current long-term debt [20]. (5) Economic Value Added (EVA) negative [5]. This study is different from previous studies by using negative retained earnings as a determining factor for financial distress.

The financial distress model needs to be developed, because knowing the company's financial distress from an early age is expected to take actions that anticipate the direction of bankruptcy. Brahmana [21] stated that there are two motives for conducting research on the financial distress of a company. The first is to examine the relationship and influence between financial factor variables and the measurement of failure or bankruptcy. The second is to develop a model in forecasting or predicting bankruptcy. In this research, it is conducted related to the first motive.The ratio used in this study is the ratio of profitability and leverage.

According to Putra [22], the profitability ratio is a ratio that measures the effectiveness of company management and executives as evidenced by the ability to create profit value. The effectiveness of the use of company assets will reduce costs incurred by the company. The company will get savings and will have sufficient funds to run its business. With sufficient funds, the company will likely experience financial distress will be smaller.

The higher the company's ability to generate profits, the less likely the company will experience financial distress. In this study, the profitability ratio is measured by ROA, indicating the ability of the capital invested in all assets to generate net profits. Profitability ratios have a negative and significant effect in predicting financial distress [23]. Research conducted by Al-Khatib [24] reveals that profitability does not affect financial distress. The Return of Asset (ROA) ratio can predict the likelihood of financial distress with a positive effect [15]. This ratio is used to measure the effectiveness of the company in managing its assets. Too many assets will cause a large capital cost, so it will reduce profits. Conversely, too small assets will cause the loss of profitable sales.

Leverage Ratio and Financial Distress According to Kasmir [25] , the leverage ratio is a ratio used to measure the extent to which the company's assets are financed by debt. This ratio can be calculated based on information from the balance sheet, namely in the accounts of assets and items of debt. According to Iskandar [15], companies that have a higher level of debt will experience financial distress and bankruptcy more easily than companies that have less debt. In this study, the leverage ratio is measured by debt to total asset. This ratio shows some of the assets used to guarantee debt. In a study conducted by Hapsari [26] , the leverage ratio affects financial distress. 


\section{Research Method}

This study uses a quantitative research approach using statistical tests. The population observed in this study are manufacturing companies listed on the Indonesia Stock Exchange from 2014-2019. The sample selection is done by using purposive sampling technique. The dependent variable used in this study is the company's financial distress, which is a categorical variable, zero for companies experiencing financial distress and one for healthy companies. The category of experiencing financial distress is seen from the company's negative retained earnings where Hess [27] said that retained earnings were still the best predictor of bankruptcy. The independent variables used in this study are leverage and profitability.

Based on the sample selection criteria, the companies that met the criteria and were sampled in this study were 137 companies. This study uses secondary data about the company's financial statements sourced from Indonesia Stock Exchange (IDX) from 2014 to 2019.

\section{Result and Discussion}

\subsection{Goodness of Fit Test and Overall Model Fit}

The Chi Square value is 277.766 with a sig value of 0.000 . From these results, it can be seen that the Sig value is smaller, namely $0.000<0.05$, meaning there is a significant difference between the predicted classification and the observed classification. This means the logistic regression model is suitable for further analysis.

The-2Log probability statistic is used to determine whether the independent variables added to the model can significantly improve the model. At Block Number $=0$ (Beginning Block), namely the first model only with constants without any independent variables, the value of $-2 \mathrm{Log}$ likelihood is 874,165 . The initial $-2 \log$ likelihood value (block number 0 result) is 874,165 and the $-2 \log$ likelihood value for block number 1 is 596,398 . With the decrease in the $-2 \log$ likelihood value, this indicates the model used is a good regression model and is feasible to use.

\subsection{Test of The Coefficient of Determination and Qualification Matrix}

The coefficient of determination in the logistic regression can be seen in the Nagelkarke $R$ Square value. The Nagelkerke R Square value is 0.438 , indicating that the ability of the independent variable to explain the dependent variable is 0.438 or 43.8 percent. Or in other words that 43.8 percent of the dependent variable (financial distress and non-distress) can be predicted by the independent variable in the form of financial ratios: ROA and DTC. While the remaining 56.2 percent can be predicted and explained by other independent variables that are unincluded in the model.

The qualification matrix will show the predictive power of the regression model to predict the likelihood of a company experiencing financial distress. The results of the overall classification, the percentage of truth for companies experiencing FD (financial distress) and NFD (non financial distress) has the same prediction figure, namely $85.2 \%$, that is, 80 observations are predicted correctly and only 18 observations are predicted to be the opposite. 


\subsection{Logistic Regression Analysis Test Results}

To test the hypothesis, a logistic regression test was used which was carried out on all variables, namely profitability and leverage in predicting financial distress. Based on Table 1 the test results are as follows:

$$
\mathrm{Y}=-1,764666+-23,606452 \mathrm{ROA}+1,673446 \mathrm{DTC}
$$

Table 1. Hypothesis Testing

\begin{tabular}{lrrrr}
\hline & B & Wald & df & \multicolumn{1}{c}{ Sig. } \\
\hline ROA & -23.606 & 95.669 & 1 & 0.000 \\
DTC & 1.673 & 15.408 & 1 & 0.000 \\
Constant & -1.764 & 50.278 & 1 & 0.000 \\
\hline
\end{tabular}

The results of hypothesis 1 testing of the profitability ratio as measured by return on assets (ROA) show a regression coefficient of -23.606 and a significance value of 0.000 . The significance value of $0.000<0.05$ means that the profitability ratio has a significant negative effect in predicting financial distress. These results support the hypothesis which states that the profitability ratio has a negative effect.

The results of hypothesis testing 2 of the leverage ratio as measured by debt to total assets (DTA) show a regression coefficient of 1,673 and a significance value of 0,000 . This result means that the leverage ratio has a significant effect in predicting financial distress.

\subsection{Discussion}

Through logistic regression, it is known that profitability has a significant influence in predicting financial distress. The results of these tests indicate that profitability has a significant and positive influence in predicting financial distress. ROA results can predict the possibility of financial distress with a positive effect. Too many assets will cause a large capital cost, so it will reduce profits. Conversely, too small assets will cause the loss of profitable sales. The greater the ratio obtained, the better because the company is quicker to convert its inventory into cash so that the possibility of financial difficulties will be smaller. This result is not in line with the hypothesis which suspects that the profitability ratio has a negative effect and is not in line with the research of Iskandar [15] who found that the ROA ratio has a negative effect on the probability of financial distress.

Through logistic regression, it is known that the leverage ratio has a significant influence in predicting financial distress. The results of these tests indicate that profitability has a significant and positive influence in predicting financial distress with a significance value of $0.015<0.05$. Companies that experience financial distress generally have a high DTA ratio and show a total and almost as large debt as their total assets and some companies even have total debt. Companies that have a greater amount of debt than their total assets generally have negative equity. So it does not rule out companies that have a high enough amount of debt will violate the debt agreement with creditors because the number of assets owned is not able to guarantee the debt owned by the company and companies that have high debt will also be charged with high interest costs while the amount of debt is higher. than the total assets of the company cause the book value of the company's 
equity to be negative. The results of this study are also consistent with the research of Spica [18] and Pasaribu [5], and Hapsari [26] which states that the leverage ratio can be used to predict financial distress conditions.

\section{Conclusions and Suggestions}

It can be concluded that the profitability ratio as measured by Return on Assets (ROA) has a negative and significant influence in predicting financial distress and the leverage ratio measured by Debt to Total Asset (DTA) has a positive and significant effect in predicting financial distress. Suggestions for management to be used as a basis for taking corrective action in which there are indications that the company is experiencing financial distress. For investors, it can be used as a basis for having a strategic plan to invest in the stock market. By paying attention to the profitability and leverage ratios proven empirically in this study, these financial ratios are able to influence financial distress. For further research, it is better to use certain measures to project the financial distress of a corporation or to use more than one proxy to assess financial distress, such as the use of interest coverage ratios, negative book value of equity and cash flow, or to use macro-economic factors which can be used to predict corporate financial distress.

\section{References}

[1] H. D. Piatt and M. B. Piatt, "Predicting corporate financial distress: Reflections on choice-based sample bias," J. Econ. Financ., vol. 26, no. 2, pp. 184-199, 2002, doi: 10.1007/bf02755985.

[2] I. Hanafi, "Prediksi Financial Distress Perusahaan Manufaktur yang Terdapat di Bursa Efek Indonesia," Univ. Diponegoro, vol. 4, no. 1, pp. 26-51, 2018.

[3] B. C. F. Yap, S. Munuswamy, and Z. Mohamed, "Evaluating Company Failure in Malaysia Using Financial Ratios and Logistic Regression," Asian J. Financ. Account., vol. 4, no. 1, May 2012, doi: 10.5296/ajfa.v4i1.1752.

[4] A. Iskandar, "Model Prediksi Financial Distress Dengan Binary Logit (Studi Kasus Emiten Jakarta Islamic Index) (Application of Binary Logit Regression on Financial Distress Prediction of Jakarta Islamic Index)," SSRN Electron. J., Mar. 2018, doi: 10.2139/ssrn.2834658.

[5] R. Bismark Pasaribu, "Financial Distress Prediction in Indonesia Stock Exchange - Case Study of Trade Industry Public Company," J. Econ., 2008.

[6] T. W. Antikasari and D. Djuminah, "Memprediksi Financial Distress Dengan Binary Logit Regression Perusahaan Telekomunikasi," J. Keuang. dan Perbank., vol. 21, no. 2, pp. 265-275, 2017, doi: 10.26905/jkdp.v21i2.654.

[7] L. T. Vu, L. T. Vu, N. T. Nguyen, P. T. Thuy Do, and D. P. Dao, "Feature selection methods and sampling techniques to financial distress prediction for Vietnamese listed companies," Invest. Manag. Financ. Innov., vol. 16, no. 1, pp. 276-290, 2019, doi: 10.21511/imfi.16(1).2019.22.

[8] J. Sun, M. Zhou, W. Ai, and H. Li, "Dynamic prediction of relative financial distress based on imbalanced data stream: from the view of one industry," Risk Manag., vol. 21, no. 4, pp. 215-242, 2019, doi: 10.1057/s41283-018-0047-y.

[9] E. Ul Hassan, Z. Zainuddin, and S. Nordin, "A Review of Financial Distress Prediction Models: Logistic Regression and Multivariate Discriminant Analysis,” J. Account. Financ., vol. 1, no. 3, pp. 
13-23, 2017.

[10] F. Mraihi, "Distressed Company Prediction using Logistic Regression: Tunisian's Case,” vol. 15, no. 3, 2015.

[11] H. Waqas and R. Md-Rus, "Predicting financial distress: Importance of accounting and firm-specific market variables for Pakistan's listed firms," Cogent Econ. Financ., vol. 6, no. 1, pp. 1-16, Jan. 2018, doi: 10.1080/23322039.2018.1545739.

[12] A. Dewi, M. Hadri, A. Dewi, and M. Hadri, "Financial distress prediction in Indonesia companies: finding an alternative model," Russ. J. Agric. Socio-Economic Sci., vol. 61, no. 1, pp. 29-38, 2017.

[13] F. Z. Kerroucha and H. Naimi, "Analysis of the Power of Predicting Financial Distress of Jordanian Industrial Firms Listed in Amman Stock Exchange Using logistic regression for the period ( 1995-," vol. 6, pp. 12-18, 2016.

[14] S. Jones and D. A. Hensher, "Predicting Firm Financial Distress: A Mixed Logit Model," The Accounting Review, vol. 79. American Accounting Association, pp. 1011-1038, 2004, doi: $10.2307 / 4093084$.

[15] A. Iskandar, "Model Prediksi Financial Distress Dengan Binary Logit ( Studi Model Prediksi Financial Distress Dengan Binary Logit ( Studi," J. BPPK, vol. Volume 8 N, no. December, 2015.

[16] M. Y. Chen, "Predicting corporate financial distress based on integration of decision tree classification and logistic regression," Expert Syst. Appl., vol. 38, no. 9, pp. 11261-11272, 2011, doi: 10.1016/j.eswa.2011.02.173.

[17] M. Schmuck, Financial distress and corporate turnaround: an empirical analysis of the automotive supplier industry. Springer Gabler, 2013.

[18] L. Spica and A. \& Kristijadi, "Analisis Rasio Keuangan Untuk Memprediksi Kondisi Financial Distress Perusahaan Manufaktur yang Terdaftar di Bursa Efek Jakarta," 2003.

[19] N. T. Hill, S. E. Perry, and S. Andes, "Evaluating Firms In Financial Distress: An Event History Analysis," J. Appl. Bus. Res., 2011, doi: 10.19030/jabr.v12i3.5804.

[20] R. B. Whitaker, "The early stages of financial distress," J. Econ. Financ., 1999, doi: $10.1007 / \mathrm{bf02745946.}$

[21] R. K. Brahmana, "Identifying Financial Distress Condition in Indonesia Manufacture Industry," $J$. Bus., pp. 1-19, 2007.

[22] H. S. R. Putra, Manajemen Keuangan dan Akuntansi Untuk Eksekutif Perusahaan. Jakarta: Salemba Empat, 2009.

[23] J. R. Lawrence, S. Pongsatat, and H. Lawrence, "The use of ohlson's o-score for bankruptcy prediction in Thailand," J. Appl. Bus. Res., vol. 31, no. 6, pp. 2069-2078, 2015, doi: 10.19030/jabr.v31i6.9468.

[24] H. B. Al-Khatib and A. Al-Horani, "PREDICTING FINANCIAL DISTRESS OF PUBLIC COMPANIES LISTED IN AMMAN STOCK EXCHANGE,” Eur. Sci. J. July Ed., vol. 8, no. 15, Jul. 2012.

[25] Kasmir, Analisis Laporan Keuangan, Cetakan 11. Rajagrafindo Persada, 2018.

[26] E. I. Hapsari, "Kekuatan Rasio Keuangan Dalam Memprediksi Kondisi Financial Distress Perusahaan Manufaktur Di BEI," J. Din. Manaj., vol. 3, no. 2, pp. 101-109, 2012.

[27] D. Hess and M. Huettemann, "Predicting Bankruptcy via Cross-Sectional Earnings Forecasts," SSRN Electron. J., Mar. 2018, doi: 10.2139/ssrn.3136978. 